\title{
French universities finally required to conform to the law
}

Paris

Now that Lionel Jospin is sure he is Minister for Education in the new French government, following two months of electoral musical chairs, he has promised to end a controversy that has upset universities for the past four years. While an alternative solution is sought, he has given 18 renegade universities until 15 October to conform to a law that has divided the academic community since it was passed in 1984.

In January 1984, Alain Savary finally saw his proposed reforms of procedures for running the universities reach the statute book. This was the first major modification to affect universities since the upheavals of 1968. But, in 1988, 25 of the 74 universities have still not conformed to all the new rules and 18 are opposed to doing so. The 'Savary Law', which changed the composition of governing bodies, the way they should be elected and the procedures for everyday university administration, has been criticized as excessively cumbersome. At recent elections in one Paris university, it took 17 rounds of voting before a new president was eventually named.

Reluctant to make the changes, several universities have counted on inertia and political uncertainty to continue, as before, with the 1968 regulations. In 1986 , with a change of government, many felt that the Savary Law would be abolished. When Alain Devaquet, then Education Minister, tried to do just this, he was forced to concede defeat in the face of student riots.

His successor, Jacques Valade, was caught in a compromise when he took over in January 1987. Unwilling to enforce the politically unpalatable Savary Law, yet dissuaded from attempting global reforms, he proposed to accept the status $q u o$, with two-thirds of the universities technically outside the law. But Valade tinkered with the Savary Law, reviving a two-tier doctoral system for some disciplines (see Nature 332, 388; 1988).

Speaking to a meeting of university presidents on 30 June, Jospin declared this situation untenable. It is the duty of ministers to enforce the law, he said, and the law is that of 1984 . If, by 15 October, some universities have still not filed statutes and changed their governing bodies, Jospin has promised to take the matter to court to ensure uniformity "by the end of the year". Jospin has already made the PhD once again the only doctorate, although he has accepted that some disciplines within the arts may interpret thesis requirements "flexibly".

Jospin is not immune to calls to make the Savary Law easier to apply, but he is unlikely to try to undertake radical changes. He has promised to draw up procedures "in the next few weeks" to simplify the rules, especially concerning the elections of university presidents and of non-academic governors. At the same time, Jospin is aiming to raise university standards and the quality of life for students.

Higher education in France is uniquely heterogeneous. Most engineers (a highly valued title in France), politicians and those with any kind of economic power come up through the elite grandes écoles, but these institutions carry out little research. Research is mostly carried out by career researchers, with little or no teaching load, in state-supported centres under the umbrella of organlzations such as CNRS and INSERM. Most of these researchers are university graduates. This forces French universities to act as halfway houses, carrying out most of the teaching, but often excluded from the academic elite

Jospin would like a better adaptation of university education to vocational requirements. At present only $30-60$ per cent (according to disciplines) of first-year students get through their examinations. Jospin wants to see the figures raised to $80-90$ per cent by improving coordination between secondary and tertiary education. $\mathrm{He}$ has also set up a working party to investigate the future of their discipline at home.

Last month, before President Mitterrand dissolved his new government, Jospin provided money in this financial year to boost library and student residence facilities (see Nature 333, 584; 1988) and promised to see the level and number of student grants raised. But, he told French television news last Thursday, students will find the situation after the summer vacation much as Jacques Valade had intended. It is too late to make changes before then, said Jospin.

If the injection of cash and energy into higher education will please students and academics, right-wing deputies in the assembly who, with the 'Centrists', still have political muscle, are already wondering where the money is going to come from.

\section{UK particle physics looks up as CERN tightens its belt}

\section{London}

THE future of particle physics in Britain is looking up after recent moves towards cutting costs at CERN, the European laboratory for particle physics, which means that Britain is likely to remain a member. The CERN Council has accepted two proposals: to change the formula for calculating each member state's annual contribution to the budget and to reduce the number of staff. The council is also considering plans to open up membership of CERN to countries outside Europe.

The new accounting system could reduce Britain's contribution to CERN by $£ 10$ million. That would reduce it from the present $£ 55$ million to a level thought to be acceptable to the government. Calculations are at present based on the relative gross domestic products of each country. But the figures are always three to six years out of date.

Britain's lagging economy and the weakness of the pound in the early $1980 \mathrm{~s}$ have meant that Britain's subscription, in sterling, has increased by more than 35 per cent although CERN's budget has remained steady in real terms. The new formula, likely to be implemented next year, will take more account of exchange rate fluctuations and bring up to date the calculation of gross domestic product.

In line with recommendations of a management review committee chaired by
Anatole Abragam of the French Atomic Energy Commission, the CERN Council has accepted there is a need to reduce staff numbers.

Over the next four years, CERN will shed 200 jobs beyond departures expected from natural wastage. By 1993, CERN will have reduced its staff by 10 per cent to just over 3,000. And by 1995 this will have produced savings of $£ 70$ million, a saving of $£ 10$ million more than proposed by the Abragam committee.

At the same time as reducing numbers, CERN hopes by recruiting $\mathbf{5 0}$ junior staff annually over the next four years to reduce the average age from the present 48 years.

Another cost-cutting move now on the discussion table at CERN is the British proposal to open membership beyond Europe's boundaries. CERN is already an international venture in that researchers from all over the world use the facilities there.

But there is increasing concern that nonmember countries do not fully pay their way. They tend to support large projects but not the basic research programme. Under the proposed scheme, such countries would have a form of associate membership and pay full economic costs for access to experiments. A working party is being set up to look into this proposal and is due to report early next year.

Christine McGourty 